\title{
Vocational and Technical Education Status of the Industry 4.0 Process in Turkey
}

\author{
Ali Durmus (Corresponding author) \\ Department of Electricity and Energy, Vocational College, \\ Kayseri University, Turkey \\ E-mail:alidurmus@kayseri.edu.tr \\ Abdulkadir Dagli \\ Department of Electricity and Energy, Vocational College, \\ Kayseri University, Turkey \\ E-mail:abdulkadirdagli@kayseri.edu.tr
}

\begin{abstract}
It is only possible for our country to become a determining actor in global competition, to ensure sustainable development in all areas, to use all its resources efficiently and effectively, only by upbringing qualified manpower. As in developed countries, studies and policies aimed at increasing the quality of Vocational and Technical Education are of great importance for the brighter future of our country. While the innovations in information and communication technologies, which are led by technological developments, continue at full speed, it is a fact that education is the most affected sector. Following this rapid change in accordance with the conditions of the day and creating the infrastructures parallel to it must be one of the main subjects of education. Synchronizing with the needs of the modern age and cooperating with all relevant sectors is important to ensure competitiveness. It is necessary for the young population, which is the most valuable resource of our country, to receive education in Vocational and Technical Education environments equipped with technology and facilities suitable for the conditions of the age for sustainable, social and economic development. Human-centered development requires an updated education system in line with technological developments. In this direction, developing strategies that are suitable for regional conditions is inevitable for the young population to have a dynamic structure. The basis of this development in industrial applications and information technologies is the new generation of software and hardware. The current era is known as the Industry 4.0 process. This process incorporates these technologies, which have lower energy consumption, less carbon emissions, can operate with higher security and are environmentally friendly compared to their previous versions. At the same time, Industry 4.0 incorporates many components such as the internet of things, data processing, cyber physical processing, augmented reality, and data center and automation robots. In this study, the new model vocational and technical education work will be emphasized in which skills suitable for the age of technology and informatics, personal entrepreneurship and teamwork are supported, and students are equipped with features such as problem solving and system design.
\end{abstract}

Keywords: Industry 4.0, vocational education, technical education, educational technologies, next generation education.

DOI: $10.7176 /$ JSTR/5-10-11

\section{Introduction}

When the historical process is examined, many changes have occurred in every field of society thanks to the industrial revolutions. With Industry 4.0, a great digital transformation has begun in today's age and societies have been affected by this transformation. When the industrial revolutions are examined in terms of their development dates; we see that industrialization began with the invention of steam engines. This process is known as the First Industrial Revolution. With the discovery of electricity, production turned into mass production and thus the Second Industrial Revolution came into play. Later, the factories working with serial production techniques were affected by the development of information technologies 
and production started with automatic control systems. This is defined as the Third Industrial Revolution. The Third Industrial Revolution has brought about radical changes between societies and states. With the development of digital and autonomous systems, industrial societies have adapted to these changes and the new industrial revolution known as Industry 4.0 has begun.

Concepts such as digitalization in production technologies, communication between objects, smart factories, and cyber physical systems have become known to today's industrial society. With these developments, values such as data exchange, efficiency, flexibility and speed were positively affected by digital manufacturing, thus changing the expectations of the service and production sector. New technologies that make life easier offer many positive opportunities for people, while increasing dependence on machines. When the developments in technologies are considered human-oriented; it is a fact that new learning and teaching systems are needed in addition to classical practices in the field of education in order to make changes easily understood by the society and to learn new professions that may arise. In this context, it is one of the most important topics of today to raise people with analytical thinking, innovation, the ability to use knowledge and skills of different societies, and the development of environmentally friendly technologies. With the new generation education systems, individuals' scientific, analytical, creative and critical thinking skills can be developed, thus providing the qualified manpower needed in new fields emerging with the Industrial 4.0 revolution. In order to achieve this, it is necessary to make a serious planning at pre-school, primary, secondary, high school and university education levels with a harmonious system structure. Personalized learning methods should be applied by giving priority to the areas of interest in order to provide each student with the appropriate level of skills. In addition, in order to achieve the targeted gains in the field of Vocational and Technical Education, training of trainers and the development of education and training programs in faculties of education are essential. On the other hand, encouraging students to prefer teacher training schools should be planned as a policy. In addition, current courses for future occupations should be included in the curriculum [1].

\section{Industrial Revolutions And Industry 4.0}

The changes in industrial production techniques that began in England in the middle of the 18th century gradually affected Europe and the world. Until the First Industrial Revolution, the economy was composed of food produced from man and animal power and soil. The discovery of new machines has caused steam engines to play an active role in production. In addition, iron production has led to major gains in the production of goods and services. These changes, expressed as the first industrial revolution, have increased the welfare of people living in Europe and America [2]. The Second Industrial Revolution corresponds to the mid-19th and 20th centuries. With the development of railways, products and services have been moved to a much greater distance. At the same time, the necessary raw material were easily supplied. With the use of electricity, there has been a variety of energy, this has a positive impact on production [3]. After the mid-20th century, the machines operating with automatic control systems started to spread with the developing technology. It can be said that the Third Industrial Revolution started late due to the impact of the Second World War. The technological needs of the war period contributed to the development of the new industrial revolution. In the years corresponding to this period developments in software also increased the capabilities of machines. In this way, new technologies have been developed in many fields, firstly in communication. Again, it was understood that the world's energy could be depleted in this period and interest in renewable energy sources increased. Sustainable development is one of the concepts of the Third Industrial Revolution [4]. The concept of Industry 4.0 was first introduced as a development plan carried out by the German Ministry of Education and Research. This department named one of the sections in this development plan as Industry 4.0. As a result of the development plan studies, Industry 4.0 strategy document was prepared by the National Academy of Science and Research of Germany and published in Hannover Messe Fair in 2013 [5]. The development of the concept of industrial revolutions is shown schematically in Figure 1 [6]. 


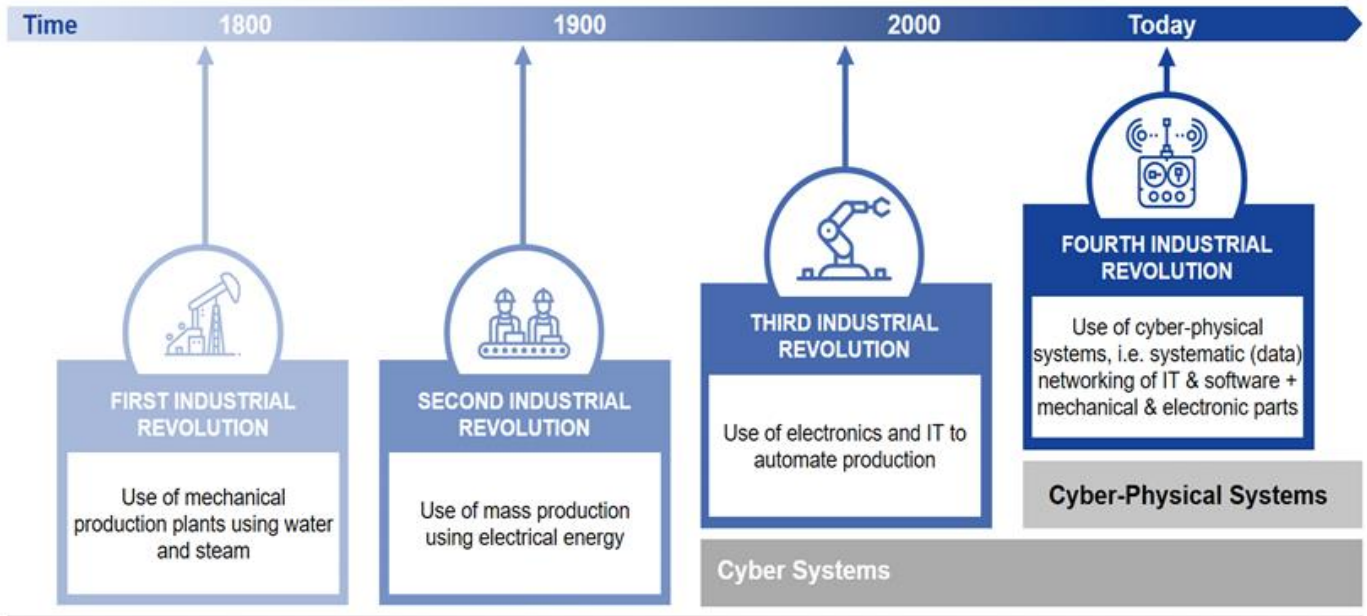

Figure 1. Stages of industrialization [6]

With the revolution of Industry 4.0, communication and information technologies, transducer and automation, robotics and artificial intelligence technologies will positively affect production and service sector in many ways and transform it into a different form. With the new industrial revolution, the entire production sector will be fully integrated with other sectors. Thus, autonomous production systems will be expanded with new customer-oriented algorithms. Thus, intelligent production technologies produced with more advanced software and hardware will increase the welfare of people. When Industry 4.0 is examined; it can be said that it is composed of basic components such as internet of objects, autonomous robots, augmented reality, cloud computing, cyber security, big data analysis and simulation. These concepts lead to innovations in many areas, including smart cities, wearable products, health services, smart manufacturing and developments in the automotive industry. In this case, the formation of new professions is inevitable. Among the new occupations envisaged are designer, cloud computing expertise, network development engineering, industrial data science, data security expertise, robot coordinator [7]. The components of the Industry 4.0 revolution are shown in Figure 2 [8].

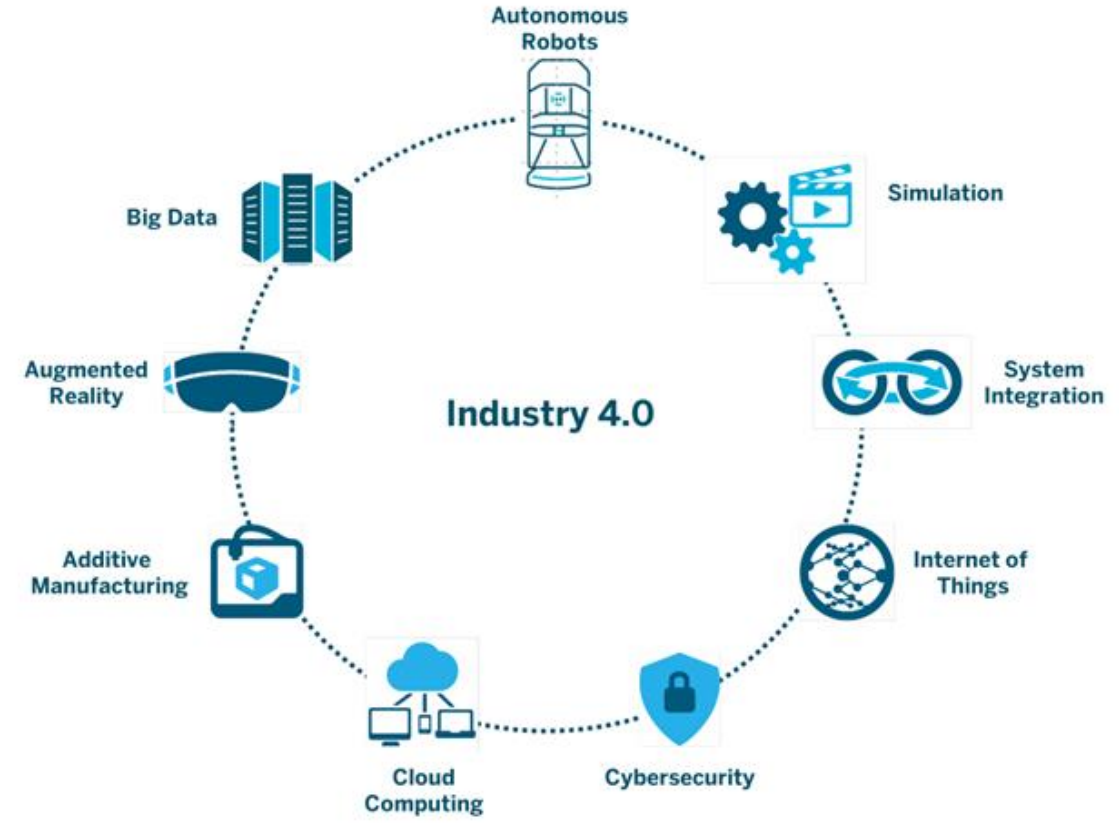

Figure 2. Stages of industrialization [6]. 


\section{Vocational And Technical Education}

Education is one of the basic elements that form the basis of social structure and social structure institutions. In today's digital age, education has been affected by this transformation along with industrial transformations. Known as the age of information and communication, today it is clear that education should adapt to this transformation considering the transfer of knowledge, social relations based on knowledge and its effects on the production sector. Educational institutions have a very important responsibility for sustainable development due to the mission of transmitting and teaching information in new industrial societies. The basic features of the new education system that develops due to this new transformation within the Industry 4.0 framework can be listed as follows:

1. Training programs should be transformed in parallel with the development of information technologies.

2. Training periods; should not be given in limited time periods such as preschool, primary school, secondary school, high school and university, should be given throughout human life and continuously.

3. There should be environments where every individual constituting a society can think freely, generate ideas, discuss and research.

4. Methods that facilitate access to information should be used by giving basic subjects away from memorization

5. Developing systems that teach learning

6. Not only verbal and numerical concepts but multi-faceted mental development training programs should be provided

Education systems adapted to today's modern age use education as a tool to transfer knowledge and developed industrial societies skills to less developed societies. This clearly demonstrates the contribution of education to globalization [9].

In the new age created by the influence of Industry 4.0, educational institutions have great responsibilities. The characteristics that all educational institutions, especially vocational and technical education structures, should possess are as follows:

- $\quad$ Organize new departments and updated curricula in accordance with Industry 4.0,

- Raising individuals who can freely think, discuss and research the place of rote understanding,

- The existing departments of all institutions providing vocational and technical education, should be Industry 4.0 aligned with

- Faculties in different branches of engineering should be opened in higher education as the technology changes rapidly and the need for R \& D will increase.

- Individual training should be provided according to their abilities and interests,

- More widespread use of digital media,

- $\quad$ Steady, planning a more flexible education model that can be shaped according to needs, from the understanding of uniform education,

- Developing virtual environments that will enable education to be given to individuals from these fields by recognizing new generations' interest in technology.

- Distance education centers and virtual laboratories should be developed,

- Coding, which is the language of the new age, should be given at all stages of education and create an infrastructure for the software sector,

- Should be able to choose courses given in different disciplines appropriate to the interest of the student instead of compulsory or limited elective courses,

Turkish education system has been planned to meet the needs of industrial society. In order to train 
manpower with the technical infrastructure to meet the demand of qualified labor force of the Industrial 4.0 revolution, our education system must immediately transition to the information society education model. The differences between these different education models are shown in Table 1 [10].

Table 1. Changing education model

\begin{tabular}{|c|c|c|}
\hline Dimensions & Industrial society education model & $\begin{array}{l}\text { Information society } \\
\text { education model }\end{array}$ \\
\hline Teacher's role & $\begin{array}{l}\text { All-knowing teacher, information } \\
\text { transmitter, expert }\end{array}$ & Router, tutor \\
\hline Student's role & Listener, passive, self-study & $\begin{array}{c}\text { Active, collaborative } \\
\text { teamwork }\end{array}$ \\
\hline Manager's role & Management leader & Teaching-management leader \\
\hline Learning method & Classroom learning & Personal research \\
\hline Learning style & Self-study learning & Teamwork learning \\
\hline $\begin{array}{c}\text { Training } \\
\text { programs }\end{array}$ & Standard training programs & Variable education programs \\
\hline $\begin{array}{c}\text { Staff } \\
\text { development }\end{array}$ & Professional development & Organizational learning \\
\hline Success criteria & $\begin{array}{c}\text { Based on memorized information } \\
\text { transfer }\end{array}$ & $\begin{array}{l}\text { Define the concepts as } \\
\text { multidimensional }\end{array}$ \\
\hline
\end{tabular}

When planning a training compatible with Industry 4.0 system; policies should be developed by developing an education model in which individuals who can think, research, discuss when necessary, develop strategies to solve problems, learn teach, learn, interdisciplinary studies and focus on learning throughout the life of the individual.

\section{Conclusions}

The rapid development of information and communication technologies has played a major role in the emergence of the concept of Industry 4.0. In today's era of digital society, the production systems based on human muscle power have disappeared and intelligent structures where artificial intelligence based objects and machines communicate with each other have come to the fore. With the machines becoming smart, full capacity production can be made without loss of efficiency, energy can be used more efficiently, and manual labor and resource consumption will be reduced. Many developed countries are giving large investments and incentives to the industry 4.0 education system. Such studies are planned within a program by TUBITAK in Turkey on January 14, 2016 but remained well below the expectations of the amount of support in the planning. On the other hand, responding to the expectations of the Industrial 4.0 revolution, state policy for transformations should be established and the support of producers, educators and the society should be sought in order to adapt to this new system. The knowledge, qualified manpower and advanced technology needed by all industrial and social components should be structured according to the new education model. It can be said that our country will have difficulty in adapting to Industry 4.0 and may lag behind the developed countries in the global race if the necessary renewal works are not carried out in all education fields, especially Vocational and Technical Education. As a result; If the developments in the Turkish education and information system develop as required by the era, sustainable economic and social development will carry our country to the level of developed countries.

\section{References}

Öztemel, Ercan. "Eğitimde Yeni Yönelimlerin Değerlendirilmesi ve Eğitim 4.0.", Üniversite Araştırmaları Dergisi 1.1 (2018): 25-30.

Drath, Rainer, and Alexander Horch. "Industrie 4.0: Hit or hype? .[industry forum]." IEEE industrial electronics magazine 8.2 (2014): 56-58. 
Jänicke, Martin, and Klaus Jacob. "A Third Industrial Revolution? Solutions to the crisis of resourceintensive growth." Solutions to the Crisis of Resource-Intensive Growth (2009).

Redclift, Michael. "Sustainable development (1987-2005): an oxymoron comes of age." Sustainable development 13.4 (2005): 212-227.

Macit, İrfan. "Kurumsal Kaynak Planlamasının Endüstri 4.0 Kazanımları: Bir Yapısal Çatı Modeli Önerisi." Yönetim Bilişim Sistemleri Dergisi 3.1: 50-60.

'FOSTEC \& COMPANY'. 2019. International Energy Agency. 10 July 2019. https://www.fostec.com/en/competences/digitalisation-strategy/industry-4-0/

Mehmet, Oktay Eldem. “Endüstri 4.0” TMMOB Emo Ankara Şubesi Haber Bülteni, 3 (2017): 10-16.

"Journal of the Korean Society for Quality Management “. 2019. 15 July 2019. https://www.jksqm.org/journal/Figure.php?xn=jksqm-45-4-677.xml\&id=F2-jksqm-45-4$677 \&$ number $=2008 \& p \_$name $=0540 \_2008$

Düzkaya, Hıdır. "Endüstri devriminde dördüncü dalga ve eğitim: Türkiye dördüncü dalga endüstri devrimine hazır mı?." Eğitim ve İnsani Bilimler Dergisi: Teori Ve Uygulama 7.13 (2016): 49-88.

Balay, Refik. "Küreselleşme, bilgi toplumu ve eğitim." Ankara Üniversitesi Eğitim Bilimleri Fakültesi Dergisi 37.2 (2004): 61-82. 